\title{
Periodontal diseases as an emerging potential risk factor for adverse pregnancy outcomes: A review of concepts
}

\author{
Olumsuz gebelik sonuçları için yeni ortaya çıkan potansiyel bir risk faktörü olarak \\ periodontal hastalıklar: kavramlarin gözden geçirilmesi
}

\author{
Jyoti Bansal, Abhishek Bansal, Navneet Kukreja, Urvashi Kukreja \\ College of Dental Sciences and Research, Maharishi Markandeshwar University, Mullana, India
}

\section{Abstract}

Preterm birth is the leading perinatal problem with subsequent morbidity and mortality in developed as well as developing nations. Among the various possible environmental, genetic, demographic, psychosocial and obstetric risk factors responsible for premature labor, poor oral health with periodontal infection has also emerged as a potential and modifiable risk factor for preterm low birth weight babies. The infected periodontium is regarded as a reservoir for periodontopathic bacteria, mainly gram negative anaerobes that serve as a source of endotoxins and lipopolysaccharides, proinflammatory cytokines and prostaglandins that enhance uterine muscle contraction leading to preterm low birth weight. Also, the progression of periodontal disease during pregnancy appears to increase the fetal growth restriction, irrespective of baseline periodontal disease status. Thus, identification and treatment of periodontal disease should be considered an important intervention strategy as a part of prenatal care to reduce adverse pregnancy outcomes. (J Turkish-German Gynecol Assoc 2011; 12: 176-80)

Key words: Adverse pregnancy outcomes, periodontal diseases, preterm low birth weight

Received: 16 April, 2011

Accepted: 23 June, 2011

\section{Özet}

Hem gelişmiş hem de gelişmekte olan ülkelerde, preterm doğum ile bunu izleyen morbidite ve mortalite önde gelen perinatal problemdir. Prematür doğumdan sorumlu çeşitli olası çevresel, genetik, demografik, psikososyal ve obstetrik risk faktörleri arasında, periodontal enfeksiyonla birlikte olan kötü ağız sağlığı da preterm düşük doğum ağırlıklı bebekler için potansiyel ve değiştirilebilir bir risk faktörü olarak ortaya çıkmıştır. Enfekte olmuş periodontium, preterm düşük doğum ağırlığına yol açan uterus kas kasilmalarını artıran endotoksinler, lipopolisakkaridler, proinflamatuvar sitokinler ve prostaglandinler için bir kaynak görevi gören başlıca gram negatif anaeroplar olmak üzere periodontopatik bakteriler için bir rezervuar olarak görülmektedir. Aynı zamanda, gebelik sırasında periodontal hastalığın ilerlemesi başlangıçtaki periodontal hastalık durumuna bakmaksızın fötal büyüme sınırlamasını artırıor görünmektedir. Sonuç olarak, adverse gebelik sonuçlarını azaltmak için prenatal bakımın bir parçası olarak periodontal hastalı̆ın tanımlanması ve tedavi edilmesi önemli bir müdahale stratejisi olarak göz önünde bulundurulmalıdır. (J Turkish-German Gynecol Assoc 2011; 12: 176-80)

Anahtar kelimeler: Advers gebelik sonuçlan, periodontal hastalıklar, preterm düşük doğum ağırlığı

Geliş Tarihi: 16 Nisan 2011

Kabul Tarihi: 23 Haziran 2011

\section{Introduction}

Gingivitis and periodontitis are two periodontal conditions of significance during pregnancy. Gingivitis is an infectious and inflammatory condition of the gingiva with prevalence estimates during pregnancy ranging from $30 \%$ to $100 \%$ (1). Periodontitis is a more severe condition that results in the destruction of tooth-supporting structures affecting $5 \%$ to $20 \%$ of pregnant women (2).

A mother giving birth "early" due to sudden trauma or stress is a worldwide problem in all population groups. Birth weight is the most important determinant of the chances of survival, growth and development of a newborn infant. The international definition of low birth weight adopted by the Twentyninth World Health Assembly in 1976 is a birthweight of "less than $2500 \mathrm{~g}$ ". Birth weights are considered to be very low when less than $1500 \mathrm{~g}$, and extremely low if less than $1000 \mathrm{~g}$. Low birth weight also results from both a short gestational period and retarded intrauterine growth. The normal gesta- tion for humans, full term is 40 weeks. The World Health Organization defines preterm birth as any live birth at less than 37 weeks of gestation. Delivery at less than 32 weeks is termed as very preterm and delivery at less than 28 weeks is extremely preterm. It is generally said that the majority of preterm births are also low birth weight (3).

Birth weight has long been a subject of epidemiological investigations concerning the associated risk factors and public health interventions. The primary cause of low birth deliveries is premature rupture of membranes (PROM). On health grounds, preterm babies suffer from respiratory distress syndrome, periventricular hemorrhage, periventricular leucomalacia, necrotizing enterocolitis, sepsis, patent ductus arteriosus, cerebral palsy, retinopathy of prematurity, mental retardation and cardiovascular malformations.

Recent evidence suggests that maternal periodontal disease is associated with adverse pregnancy outcomes including early pregnancy loss, preterm birth, low birth weight, and preeclampsia (4). Over the last decade, great interest has been generated to support the hypothesis that subclinical infection, 
including maternal periodontal infection, is an important cause of preterm labor. Therefore, the present literature summarizes the concepts and mechanisms concerning periodontal infection and adverse pregnancy outcomes.

\section{Risk factors for preterm and lowbirth weight}

Among the various possible environmental, genetic, demographic, psychosocial and obstetric risk factors responsible for premature labor, poor oral health with periodontal infection has also emerged as a potential risk factor during the past decade (Fig. 1). However, it is not clear how these predictors are interrelated, or if multiple factors act synergistically to affect the risk for preterm birth. Since there is a strong potential for confusion, especially in smaller epidemiological studies, it becomes difficult to identify a true risk factor responsible for preterm birth. Risk factors can be considered primary if they are present before the pregnancy, or secondary if they develop during the course of the pregnancy. Primary risk factors could be black race, young mothers, low socio-economic status, stress or depression, cigarette smoking, low body mass index, low maternal weight gain before pregnancy, previous history of preterm birth or abortion, chronic lung disease, hypertension, diabetes and renal disease. Secondary factors could be no or inadequate prenatal care, in vitro fertilization, pre-eclampsia, elevated fetal fibronectin, alkaline phosphatase, early contractions, vaginal bleeding in the first or second trimester, bacte- rial vaginosis, especially early in pregnancy, chorioamnionitis, placenta previa and multiple foetuses (5). Probably the most consistent predictor of preterm birth is the history of previous preterm birth (6).

\section{Physiology of labor at term}

The mechanisms involved in the initiation of labor in women are not fully understood, although prostaglandins appear to play a crucial role, and prostaglandin E2 can be used to induce human labor. The earliest identified events during labor are increase in the bioavailability of prostaglandin F2a (PGF2a) and the receptors for the hormone oxytocin. Oxytocin is one of the most potent agents that stimulate uterine contractions. Also, increase in oxytocin receptors during labor, the stretching of the cervix and myometrium have been thought to initiate a neurogenic reflex to the neurohypophysis of the pituitary gland, which acts as a positive feedback for oxytocin production (7). The obligatory precursor for prostanoid synthesis is free arachidonic acid that increases in the amniotic fluid during spontaneous labor. Fetal membranes contain phospholipids and a significant amount of arachidonic acid which is esterified on these phospholipids. These membranes also contain phospholipase A2, which can split arachidonic acid from the phospholipids. It has been suggested that bacterial sources of phospholipase A2 may be significant in the intiation of premature labor (8).

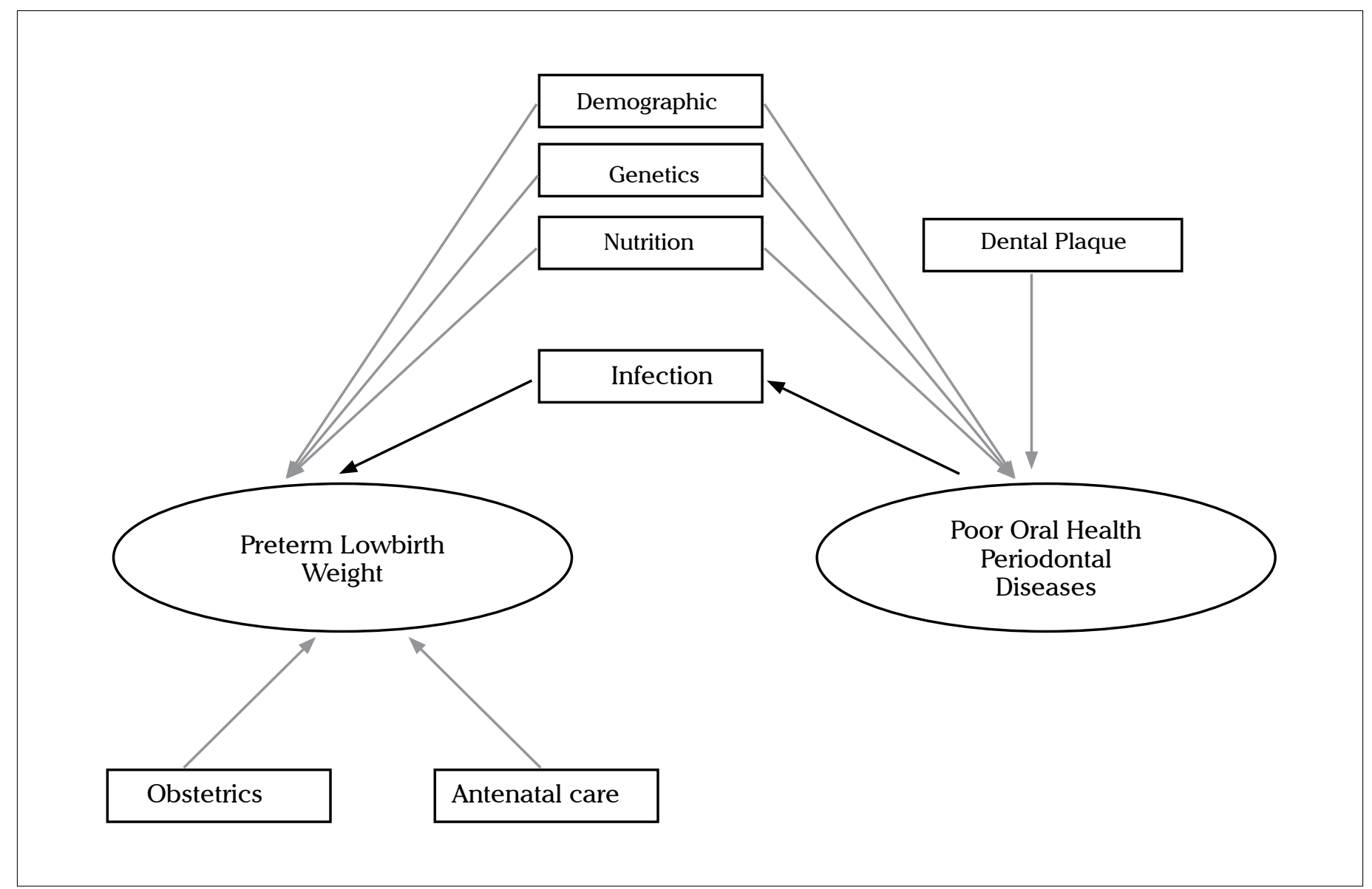

Figure 1. Multifactorial nature of risk factors for preterm labor and their interactions 


\section{Mechanism of preterm labor}

The possible mechanisms for preterm labor are infection, inflammation, placental ischaemia, hemorhage and stress that interplay to cause preterm rupture of the membranes. (Fig. 2)

There is now evidence linking maternal infection with preterm delivery. Maternal infection could be subclinical or nondetectable cases of bacterial vaginosis, prenatal events unrelated to infection and maternal periodontal infections. Bacterial vaginosis and genitourinary tract infection have been linked with a $60 \%$ increase in the risk of preterm delivery. Subclinical infection has also been shown to be linked to preterm birth (9).

\section{Markers of infection in preterm labor and periodontitis}

The primary site of infection is the membranes or decidua and not the amniotic fluid during infection induced premature labor. Recent studies have sought potentially more sensitive markers of infection. These markers have been identified in women presenting with risk for preterm labor and periodontitis. The various biochemical markers of infection for preterm birth and periodontitis are:

1. Prostaglandins.

2. Phospholipase $\mathrm{A}_{2}$ produced by genital tract anaerobes responsible for prostaglandin sysnthesis.

3. Inflammatory cytokines such as IL-6 and tumor necrosis factor. IL-6 is reported to stimulate prostaglandin release by human amnion and deciduas in women with preterm labor associated with infection (10) as well as women who experience spontaneous abortion (11).

4. Bacterial products such as endotoxins that stimulates uterine muscle contractions.

5. Increased fetal adrenal cortisone production.

Thus, combinations of increased prostaglandins production, increased fetal cytokine and chemokine production, bacterial toxins and fetal adrenal cortisone production may lead to myometrial contractions, membrane rupture, cervical ripening and preterm delivery (12).

\section{Periodontal infection and adverse pregnancy outcome}

The association between maternal periodontal disease and preterm birth was first reported by Offenbacher in 1996 (13). He conducted a case control study enrolling 124 pregnant or postpartum mothers with and without the presence of periodontal disease. The study concluded that preterm or low birth weight mothers had significantly worse periodontal conditions than respective normal birth weight controls. In a meta-analytic systematic review of 17 articles, Vergnes and Sixou (2007) found a statistically significant association between periodontitis and adverse pregnancy outcomes (14). Guimaraes AN conducted a study to address the possible association between maternal periodontal disease and preterm or extreme preterm birth. The results of the study indicate that periodontal disease in the mothers, besides being associated with preterm birth, as indicated in most literature reports, is also related to extreme preterm birth (15).

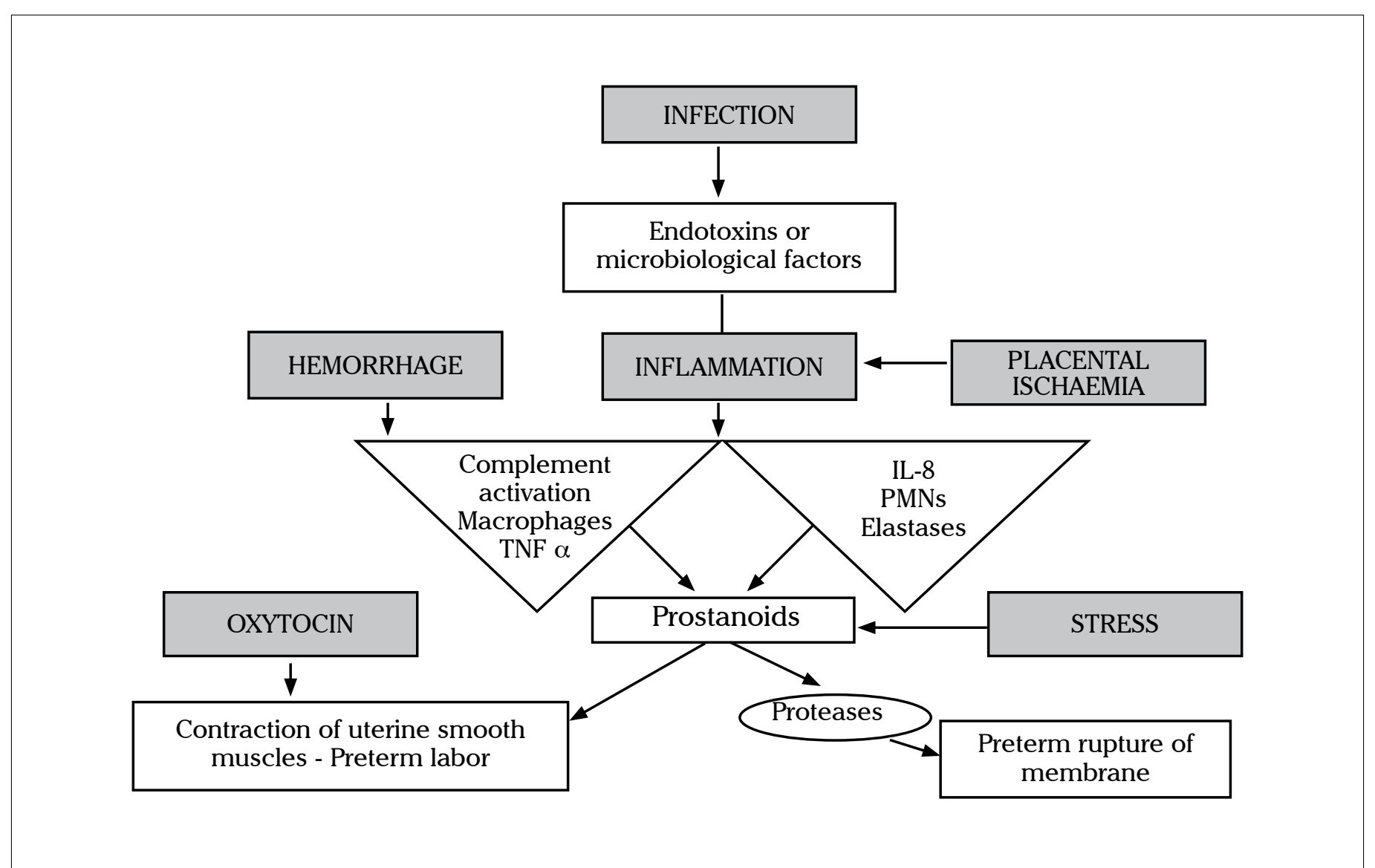

Figure 2. Possible mechanisms of preterm labor 
Current understanding of the biological events surrounding preterm labor strongly suggests that prostaglandins and proinflammatory cytokines play a pivotal role in the initiation process. In a later study, Offenbacher (16) explained the key mechanism through which periodontal infection is linked to preterm low birth weight. He proposed that alterations in the levels of these inflammatory mediators resulting from the normal host response to an infectious agent enhances maternally or fetally derived proinflammatory cytokines, polymorphonuclear leukocytes and phospholipase A2 production enhances prostaglandin production or directly to uterine muscle contraction. The second hypothesis regarding the spread of infection could be either through microbes or their toxins that enter the uterine cavity either by an hematogenous route via transient bacteremia or they could be introduced into the vagina by the ascending route from the lower genital tract. In either case, a key issue which is unresolved but is highly pertinent to the potential role of periodontal infection and preterm low birth weight involves the site of action of the infectious challenge and resulting inflammatory response. It has also been suggested that mechanisms such as genetic predisposition for a hyperinflammatory response may be responsible for periodontitis and adverse pregnancy outcomes (17).

The infected periodontium is regarded as a reservoir for periodontopathic bacteria, mainly gram negative anaerobes that serve as a source of endotoxins and lipopolysaccharides, proinflammatory cytokines and prostaglandins that have been shown to be increased in subjects with periodontitis (18). Boggess and colleagues (19) have also confirmed that risk for preterm birth may be highest when the foetus is exposed to periodontal bacteria that generate an inflammatory response. They measured levels of C-reactive protein, 8-isoprostane, prostaglandin E2 and IgM specific against Campylobacter rectus, Peptostreptococcus micros, Prevotella nigrescens, Prevotella intermedia, or F. nucleatum in cord blood samples from preterm and full-term births. The risk of preterm birth ( $<35$ weeks) was highest when both detectable levels of IgM against at least one pathogen and elevated levels of any of the inflammatory mediators were present. Furthermore, animal experiments where pregnant hamsters challenged with Porphyromonas gingivalis, a gramnegative bacterium frequently associated with periodontitis, have shown significant association between increasing levels of both prostaglandin E2, tumor necrosis factor $\alpha$ and fetal growth retardation or reduced fetal birth weight (20). Recently, a study conducted by Adriaens et al. investigated the impact of pregnancy on subgingival microbiota. The authors concluded that although subgingival levels of A. actinomycetemcomitans, P. gingivalis, T. forsythia, and T. denticola did not change, elevated levels of $P$. gingivalis and $T$. forsythia were associated with bleeding on probing at week 12 of pregnancy (21).

Offenbacher (22) conducted a five year prospective study on oral conditions and pregnancy (OCAP) to find out an association between periodontitis and the risk of preterm birth and fetal growth restriction. The study concluded with the hypothesis that untreated moderate to severe maternal periodontal disease is an independent risk factor for preterm birth (less than 37 weeks), low birth weight (less than 2500 gms) and fetal growth restriction (small weight for gestational age) after adjusting for traditional obstetric risk factors and covariates. The progression of periodontal disease during pregnancy appears to increase the fetal growth restriction, irrespective of baseline periodontal disease status. In the second part of his study, preterm birth resulting from systemic dissemination of the maternal periodontal infection was assessed in the absence of protective antibodies. The study concluded that mothers who did not mount a strong IgG response to certain periodontal pathogens experienced the highest percentage of preterm births (23).

Jeffcoat (24) analyzed multiple epidemiological studies to suggest cause and effect relationships between the maternal periodontal health and preterm birth. To address cause and effect association, periodontal disease must be present prior to preterm birth and the treatment of periodontal infection in pregnant females can lower the risk of adverse pregnancy outcome. If conventional periodontal therapy reduces the risk of preterm birth, then it needs to be established what type of therapy and at what trimester of pregnancy periodontal therapy must be delivered to achieve the most efficacious reduction in the risk of adverse pregnancy outcomes. Mitchell-Lewis et al. (2001) investigated the effect of periodontal treatment on preterm births and/or low birth weight in a cohort of young 74 pregnant women compared with 90 post-partum women. Although the incidence of adverse pregnancy outcomes was higher in women without periodontal treatment, this difference was not statistically significant (25).

In contrast, López et al. observed a significant reduction in the rate of preterm births and/or low birth weight in women that had received periodontal treatment before the $28^{\text {th }}$ gestation week when compared with women who had not received any treatment (26). Later in a pilot study by Offenbacher et al. (2006), it was observed that periodontal treatment significantly reduced the incidence of preterm births, in spite of the small size of the sample (53 women) (27). Therefore, large scale longitudinal epidemiological and intervention studies are necessary to validate the causal relationship of periodontal diseases to adverse pregnancy outcomes.

\section{Conclusion}

The magnitude of effect of periodontal infection on adverse pregnancy outcome suggests that periodontitis is a significant emerging risk factor but clearly insufficient to establish a cause and effect relationship. As the periodontal disease is preventable and treatable, therefore, future prospective studies are required to ascertain the potential effects of periodontal therapy on the rate of prematurity. Thus, identification and treatment of periodontal disease should be considered an important intervention strategy as part of prenatal care to ensure the best possible start to life by reducing the adverse pregnancy outcomes.

\section{Conflict of interest}

No conflict of interest was declared by the authors.

\section{References}

1. Laine MA. Effect of pregnancy on periodontal and dental health. Acta Odontol Scand 2002; 60: 257-64. [CrossRef]

2. Offenbacher S. Maternal periodontal infections, prematurity, and growth restriction. Clin Obstet Gynecol 2004; 47: 808-21. [CrossRef]

3. Anonymous. The prevention of perinatal mortality and morbidity. Report of a WHO expert committee. World Health Organ Tech Rep Ser 1970: 457: 1-60. 
4. Xiong X, Buekens P, Fraser WD, Beck J, Offenbacher S. Periodontal disease and adverse pregnancy outcomes: A systematic review. BJOG 2006; 113: 135-43. [CrossRef]

5. Goffinet F. Primary predictors of preterm labour. BJOG 2005; 112 : 38-47. [CrossRef]

6. Mercer BM, Goldenberg RL, Das A, Moawad AH, Iams JD, Meis PJ, Copper RL, Johnson F, Thom E, McNellis D, Miodovnik M, Menard MK, Caritis SN, Thurnau GR, Bottoms SF, Roberts J. The preterm prediction study: a clinical risk assessment system. Am J Obstet Gynecol 1996; 174: 1885-93. [CrossRef]

7. Chard T. Oxytocin in human parturition. In Chard T, Grudzinskas JG, et al. The uterus. 1st edn. Cambridge University Press, 1994.

8. Bejar P, Curbelo V, Davis C, Gluck L. Premature labor. II. Bacterial sources of phospholipase. Obstet Gynecol 1981; 547: 479-82. [CrossRef]

9. Minkoff H, Grunebaum AN, Schwarz RH, Feldman J, Cummings PHM, Crombleholme W, Clark L, Pringle G, McCormack WM. Risk factors for prematurity and premature rupture of membranes: A prospective study of the vaginal flora in pregnancy. Am J Obstet Gynecol 1984; 150: 965-72.

10. Mitchell MD, Dudely DJ, Edwin SS, Schiller SL. Interleukin 6 stimulates prostaglandin production by human amnion and decidual cells. Eur J Pharmacol 1991; 192: 189-91. [CrossRef]

11. Romero R, Munoz H, Gomez R. Two third of spontaneous abortions or fetal deaths after genetic midtrimester amniocentesis are the result of pre-existing subclinical inflammatory process of the amniotic cavity. Am J Obstet Gynaecol 1995; 172: 261. [CrossRef]

12. Goldenberg RL, Hauth JC, Andrews WW. Intrauterine infection and preterm delivery. N Engl J Med 2000; 342: 1500- 7. [CrossRef]

13. Offenbacher S, Katz V, Fertik G, Collins J, Boyd D, Maynor G, McKaig $\mathrm{R}$, Beck J. Periodontal infection as a possible risk factor for preterm low birth weight. J Periodontol 1996; 67: 1103-13. [CrossRef]

14. Vergnes JN, Sixou M. Preterm low birth weight and maternal periodontal status: a meta-analysis. Am J Obstet Gynecol. 2007; 196: 135.e1-7. [CrossRef]

15. Guimaraes AN, Silva-Mato A, Miranda Cota LO, Siqueira FM, Costa FO. Maternal Periodontal Disease and Preterm or Extreme Preterm Birth: An Ordinal Logistic Regression Analysis. J Periodontol 2010; 81: 350-8.

16. Offenbacher S, Jared HL, O'Reilly PG, Wells SR, Salvi Ge, Lawrence HP. potential pathogenic mechanisms of periodontitis associ- ated pregnancy complications. Ann Periodontol 1998; 3: 233-50. [CrossRef]

17. Dashash $M$, Nugent $J$, Baker $P$, Tansinda D, Blinkhorn F. Interleukin-6-174 genotype, periodontal disease and adverse pregnancy outcomes: A pilot study. J Clin Immunol 2008; 28: 237-43. [CrossRef]

18. Moss M, Beck J, Genco R, Salvi G, Offenbacher S. Progressing periodontitis is associated with increased serum tumour necrosis factor alpha TNFa. J Dent Res 1995; 74: 158-63.

19. Boggess KA, Moss K, Madianos P, Murtha AP, Beck J, Offenbacher S. Fetal immune response to oral pathogens and risk of preterm birth. Am J Obstet Gynecol 2005; 193: 1121-6. [CrossRef]

20. Collins JG, Windley HW 3rd, Arnold RR, Offenbacher S. Effects of a Porphyromonas gingivalis infection on inflammatory mediator response in pregnancy outcome in hamsters. Infect Immun 1994; 62: 4356-61.

21. Adriaens LM, Alessandri R, Sporri S, Lang NP, Persson GR. Does Pregnancy Have an Impact on the Subgingival Microbiota? J Periodontol 2009; 80: 72-81. [CrossRef]

22. Offenbacher S, Lieff S, Boggess KA, Murtha AP, Madianos PN, Champagne $\mathrm{CM}$ et al. Maternal periodontitis and prematurity. Part I: obstetric outcome of prematurity and growth restriction. Ann Periodontol 2001; 6: 164-74. [CrossRef]

23. Madianos PN, Lieff S, Murtha AP, Boggess KA, Auten RL Jr, Beck JD, et al. Maternal periodontitis and prematurity. Part I: obstetric outcome of prematurity and growth restriction. Ann Periodontol 2001; 6: 175-82. [CrossRef]

24. Jeffcoat MK, Geurs NC, Reddy MS, Goldenberg RL, Hauth JC Current evidence regarding periodontal disease as a risk factor in preterm birth. Ann Periodontol 2001; 6: 183-8. [CrossRef]

25. Mitchell-Lewis D, Engebretson SP, Chen J, Lamster IB, Papapanou PN. Periodontal infections and pre-term birth: early findings from a cohort of young minority women in New York. Eur J Oral Sci 2001; 109: 34-9. [CrossRef]

26. López NJ, Smith PC, Gutierrez J. Periodontal therapy may reduce the risk of preterm low birth weight in women with periodontal disease: a randomized controlled trial. J Periodontol 2002; 73: 911-24. [CrossRef]

27. Offenbacher S, Lin D, Strauss R, McKaig R, Irving J, Barros SP, et al. Effects of periodontal therapy during pregnancy on periodontal status, biologic parameters, and pregnancy outcomes: a pilot study. J Periodontol 2006; 77: 2011-24. [CrossRef] 